\title{
ARCHITECTURAL HISTORY
}

JOURNAL OF THE SOCIETY OF ARCHITECTURAL HISTORIANS OF GREAT BRITAIN * VOLLME \& * 1905 


\section{ARCHITECTURAL HISTORY}

\section{THE JOURNAL OF THE SOCIETY OF ARCHITECTURAL HISTORIANS OF GREAT BRITAIN}

PRODUCED AT THE SCHOOL OF ARCHITECTURE

UNIVERSITY OF NEWCASTLE UPON TYNE

$$
\text { for }
$$

THE SOCIETY OF ARCHITECTURAL HISTORIANS OF GREAT BRITAIN 
EDITORIAL COMMITTEE

Bruce Allsopp
Howard Colvin
F. Fielden

Frank I. Jenkins

(Honorary Editor)

Betty Bicket

(Editorial Assistant)

Set in Pilgrim 10 on Il point by

NORTHUMBERLAND PRESS LIMITED

GATESHEAD

and printed by

UNIVERSITY OF NEWCASTLE UPON TYNE

PRINTING SECTION 


\section{CONTENTS}

Page

Officers and Executive Committee 1963-64 - - - - - 5

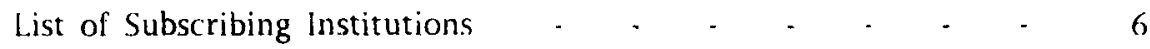

The Protectorate Citadels of Scotland, by A. A. Tait - - - - 9

Ambrose Phillipps of Garendon, by Mark cirouard - _ _ - 25

The Restoration of the Temple Church:

Ecclesiology and Recrimination, by 1. Mordaunt Crook - - 39

Letters of Philip Webb and his Contemporaries, by John Brandon-Jones $\quad 52$

All Saints' Church, Margaret Street, Reconsidered, by Paul Thompson 73

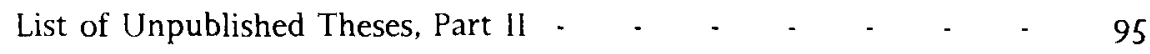

The Alice Davis Hitchcock Medallion 1963 - $\quad$ - $\quad$ - $\quad$ - $\quad 99$

Minutes of the Annual General Meeting I963 - _ _ _ _ Ioo

The Society of Architectural Historians of Great Britain - - _ - IOI

Supplement: The Roofs of York Minster, by C. IV.D. Green - - Io5 
Correspondence concerning the Society should be addressed to:

The Honorary Secretary.

Society of Architectural Historians of Great Britain. Deneholme,

Clayton Road,

Newcastle upon Tyne 2.

Correspondence concerning membership should be addressed to:

The Honorary Treasurer.

Society of Architectural Historians of Great Britain, The School of Architecture,

The University.

Manchester I3.

Correspondence concerning the Journal should be addressed to:

The Honorary Editor,

Society of Architectural Historians of Great Britain, The School of Architecture.

The University,

Manchester I3. 